J. Clin. Chem. Clin. Biochem.

Vol. 19, 1981, pp. 75-79

\title{
Evaluation of a Sensitive Radioimmunoassay of Plasma Corticotropin Using Commercial Reagents ${ }^{1)}$
}

By M. Schöneshöfer, B. Schefzig, A. Fenner, B. Weber and H. J. Dulce

Institute of Clinical Chemistry and Clinical Biochemistry Klinikum Steglitz, Freie Universität Berlin

(Received May 12/August 18, 1980)

Summary: A radioimmunological method for the sensitive estimation of plasma corticotropin immunoreactivity (ACTH) using commercially available reagents is presented. The method involves silica extraction of corticotropin from plasma, desorption with acid protein solution, neutralization and subsequent radioimmunoassay (RIA). [ $\left.{ }^{125} I\right]$ corticotropin is added as internal standard to the plasma sample. The amounts of corticotropin extractable with silica differed considerably between the plasma samples of individual subjects. There were marked differences in the affinity of five different corticotropin standards to the antiserum used. The detection limit of the method was found to be $1.47 \mathrm{pmol} / \mathrm{l}$. Blanks arising in water and in charcoal stripped serum were lower than the detection limit. Precision and accuracy were within the range commonly achieved for RIA-methods. Morning levels of normal subjects ranged from $6.5-10.9-18.5 \mathrm{pmol} / \mathrm{l}$. Hydrocortisone infusion suppressed plasma corticotropin from $12.6 \pm 6.4$ (S. D.) to $4.4 \pm 3.1$ (S. D.) pmol/l. Infusion of metyrapone increased corticotropin levels from $7.3 \pm 4.2$ (S. D.) to $15.3 \pm 6.0$ (S. D.) $\mathrm{pmol} / \mathrm{l}$.

\section{Entwicklung eines empfindlichen Radioimmunoassays zur Bestimmung von Corticotropin im Plasma unter Verwen- dung kommerziell erhältlicher Reagenzien}

Zusammenfassung: Es wird eine radioimmunologische Methode zur empfindlichen Bestimmung von Corticotropin im menschlichen Plasma unter Verwendung kommerziell erhältlicher Reagenzien beschrieben. Die methodischen Schritte bestehen im einżelnen aus einer Kieselgel-Extraktion von Corticotropin aus Plasma, Desorption mi: einer sauren Proteinlösung, Neutralisation und abschließendem Radioimmunoassay. [ ${ }^{125}$ I]Corticotropin wird als interner Standard zur Plasmaprobe gegeben. Die an Kieselgel extrahierbaren Corticotropin-Mengen unterscheiden sich signifikant zwischen den Proben verschiedener Individuen. Fünf verschiedene Corticotropin-Standards wiesen deutlich unterschiedliche Affinitäten zu dem in der Methode angewandten Antiserum auf. Die Nachweisgrenze der Methode ist $1,47 \pm 0,29(\bar{x} \pm s)$ pmol/1. Der ,Blank - Wert in Wasser und in mit Aktivkohle extrahiertem Serum war niedriger als die Nachweisgrenze. Präzision und Richtigkeit waren in dèr Größenördnung, die allgemein mit der radioimmunologischen Technik erreicht wird. Der Normalbereich morgendlicher Corticotropin-Konzentrationen betrug 6,5 - 10,9 - 18,5 pmol/1. Durch eine Infusion von Hydrocortison wurden die Konzentrationen von Corticotropin im Plasma von $12,6 \pm 6,9(\overline{\bar{x}} \pm \mathrm{s})$ auf $4,4 \pm 3,1(\overline{\mathrm{x}} \pm \mathrm{s}) \mathrm{pmol} / 1$ supprimiert. Nach einer Infusion von Metopiron stiegen sie von $7,39 \pm 4,2(\overline{\bar{x}} \pm \mathrm{s})$ auf $15,38 \pm 6,02(\overline{\mathrm{x}} \pm \mathrm{s}) \mathrm{pmol} / \mathrm{l}$ an.

\section{Introduction}

Availability of plasma corticotropin radioimmunoassays has contributed enormously to the understanding of the pituitary-adrenal axis under physiological and pathological conditions $(1,2)$. A reliable estimation, however, has to do justice to several challenges especially inherent in corticotropin analysis, such as the extremely low physiological concentrations of corticotropin in blood (3), too rapid destruction of the corticotropin molecule by proteolytic enzymes (4), and the presence of endoge- nous corticotropin-binding proteins in plasma (5). Sufficient sensitivity, which is of special importance for the detection of suppressed plasma levels, e.g. in primary hyperadrenocorticism (6), is generally achieved by extracting corticotropin from greater quantities of plasma (7-10). In the literature, only a few assays $(11,12)$, in-

\footnotetext{
1) The paper was presented in part to the European Conference on Biochemical and Instrumental Analysis, München, April 1978
} 
cluding a radioimmunoassay (RIA) kit marketed by CISSorin (13), are reported to be feasible in unextracted plasma. Although antisera used in these assays exhibit high affinity to the corticotropin molecule, they are not able to monitor distinctly suppressed corticotropin values in plasma. In addition, in these direct assays, potentially interfering binding proteins are ignored, which may account for anomalous results recently reported for the RIA kit (14).

The purpose of the present study was to develop an corticotropin RIA particularly featuring the following points:

1. to be sufficiently sensitive for the differential diagnosis of Cushing's syndrome,

2. to monitor procedural losses of individual samples,

3. to be practicable and easily accessible for routine laboratories.

\section{Materials and Methods \\ Reagents and solutions}

1-39 Corticotropin (A) (synthetic, human $210 \mathrm{IU} / \mathrm{mg}$ ) from CEA, Gif-sur-Yvette (France), purchased from IDW (Frankfurt, FRG); 1-24 corticotropin (B) (synthetic, $100 \mathrm{IU} / \mathrm{mg}$ ) from CIBA (Basel, Switzerland); 1-39 corticotropin (C) (porcine, $160 \mathrm{IU} / \mathrm{mg}$ ) from Ferring (Kiel, FRG); 1-39 corticotropin (D) (porcine, grade I, $150 \mathrm{IU} / \mathrm{mg}$ ) from Sigma (Munich, FRG); 1-39 corticotropin (E) (human) from Amersham (Buckinghamshire, England). Anti 1-39 corticotropin (porcine) and [ $\left.{ }^{125} \mathrm{I}\right] 1-39$ corticotropin (porcine) with specific activity of $11.8 \mathrm{GBq} / \mathrm{mg}$ were components of the CIS-Sorin-RIA kit (purchased from IDW, Frankfurt).

$1 \mathrm{~mol} / 1 \mathrm{HCl}, 1 \mathrm{~mol} / 1 \mathrm{NaOH}, \mathrm{EDTA}$, mercaptoethanol (all analytical grade) from Merck (Darmstadt, FRG); Quso G-32 from Philadelphia Quartz Co., (Philadelphia, PA, USA); bovine serum albumin from Behring Werke (Marburg, FRG); Dextran T40 from Pharmacia (Uppsala, Sweden); charcoal Norit A from Serva (Heidelberg, FRG); aprotinin (Trasylol ${ }^{\circledR}$ ) from Bayer (Leverkusen, FRG); metyrapone from CIBA (Basel, Switzerland); dexamethasone from Ferring (Kiel).

Bovine serum albumin solution A: $2 \mathrm{~g}$ of bovine serum albumin was dissolved in $100 \mathrm{ml}$ of $0.15 \mathrm{~mol} / 1 \mathrm{HCl}$ and stored at $4{ }^{\circ} \mathrm{C}$.

Bovine serum albumin solution $\mathrm{B}: 100 \mathrm{ml}$ of $0.115 \mathrm{~mol} / 1 \mathrm{HCl}$ containing $20 \mathrm{~g} / 1$ of bovine serum albumin were mixed with 20 $\mathrm{ml}$ of $0.525 \mathrm{~mol} / 1 \mathrm{NaOH}$.

EDTA solution: $5 \mathrm{~g}$ of EDTA were dissolved in $100 \mathrm{ml}$ of water. Stabilizer: for $10 \mathrm{ml}$ of blood, a mixture of $10 \mathrm{mg}$ EDTA $(200$ $\mu$ l of the EDTA solution), $4000 \mathrm{KIU}$ of aprotinin (Trasylol ${ }^{\circledR}$, $200 \mu \mathrm{l}$ of original solution) and $20 \mu \mathrm{l}$ of mercaptoethanol were used.

Corticotropin-free serum (F-serum): $100 \mathrm{ml}$ of normal hüman serum was mixed with $5 \mathrm{~g}$ of charcoal. After storage overnight at ambient temperature, aliquots of the mixture were centrifuged at $15000 \mathrm{~g}$ for $20 \mathrm{~min}$ and the supernatant was stored at $-20^{\circ} \mathrm{C}$ until used.

Barbital buffer I: $0.02 \mathrm{~mol} / 1$ barbital buffer $\mathrm{pH} 8.6$ containing $2 \mathrm{~g} / \mathrm{l}$ mercaptoethanol.

Barbital buffer II: $0.07 \mathrm{~mol} / 1$ barbital buffer $\mathrm{pH} 8.6$ containing $2 \mathrm{~g} / 1$ mercaptoethanol

Gamma-radioactivity was measured in a Gamma-spectrometer (Type RI 200, Fa. Riedel).

\section{Procedures}

\section{Sample preparation}

$10 \mathrm{ml}$ of blood were drawn in an ice-coled plastic tube containing the stabilizer, carefully mixed and centrifuged immediately at $4{ }^{\circ} \mathrm{C}$. The plasma was frozen at. $-20^{\circ} \mathrm{C}$ until analysis. Before assay, the plasma was thawed and recentrifuged at $8000 \mathrm{~g}$ for $10 \mathrm{~min}$ to remove precipitates.

\section{Extraction of corticotropin from plasma}

$2 \mathrm{ml}$ of plasma were pipetted into a plastic tube, containing 36 Bq of [ ${ }^{125}$ I] corticotropin (dissolved in $100 \mu$ l of barbital buffer I) and equilibrated for $60 \mathrm{~min}$. After addition of $20 \mathrm{mg}$ of Quso G-32 (suspended in $500 \mu \mathrm{l}$ of barbital buffer I) to the samples, the tubes were thoroughly mixed on a rotatory mixer for 3 $\mathrm{min}$. The suspension was centrifuged at $5000 \mathrm{~g}$ for $1.0 \mathrm{~min}$, the supernatant decanted and the pellet washed with $3 \mathrm{ml}$ of water. The pellet was resuspended in $1 \mathrm{ml}$ of the acid bovine serum albumin solution $A$ and thoroughly mixed for 30 min. After centrifugation at $8000 \mathrm{~g}, 1 \mathrm{ml}$ of the supernatant was carefully transferred into a plastic tube. At this step, individual procedural losses were monitored by measuring gamma-radioactivity in the tubes. Finally, $0.2 \mathrm{ml}$ of $0.525 \mathrm{~mol} / 1 \mathrm{NaOH}$ were added, and $0.5 \mathrm{ml}$. duplicates of the complete extraction solution were assayed by RIA.

\section{Radioimmunoassay}

The radioimmunoassay was set up in polystyrene tubes $(1.5 \mathrm{x}$ $45 \mathrm{~mm}$ ). The lyophilized reagents, $\left[{ }^{125}\right.$ I] corticotropin, corticotropin-antiserum and corticotropin-standards, were reconstituted in distilled water according to the manufacturer's instructions. The complete pipetting protocol for RIA is outlined in table 1.

In a pilot study, we evaluated the affinity of different commercially available corticotropin-standards to the antiserum applied. For this purpose, the corticotropin standards B, C and D, which were provided as crystalline reagents, were dissolved in the bovine serum albumin solution $B$ and diluted in the same medium up to the appropriate concentration of the standard curve (each standard dissolved in $500 \mu$ l of bovine serum albumin solution B). Corticotropin-free serum $(100 \mu \mathrm{l})$ was used instead of the serum standards in these cases. The corticotropin standards $A$ and $E$ supplied as serum reagents were set up as outlined in table 1.

After incubation of the mixture at $4{ }^{\circ} \mathrm{C}$ for $24 \mathrm{~h}$, separation of free and bound corticotropin was achieved by the dextran coated charcoal method. $10 \mathrm{mg}$ of charcoal suspended in $100 \mu \mathrm{l}$ of barbital buffer I were added simultaneously to all RIA tubes. After mixing and centrifugation at $2000 \mathrm{~g}$ for $10 \mathrm{~min}$, the supernatants were simultaneously decanted and measured for radioactivity. Evaluation of the RIA data was done by a computer program using the spline approximation technique as standard curve model (15).

Tab. 1. Protocol of the pipetting procedure of the corticotropin RIA. Values are in $\mu \mathrm{l}$.

\begin{tabular}{|c|c|c|c|c|}
\hline . & $\begin{array}{l}\text { Zerö } \\
\text { tubes }\end{array}$ & $\begin{array}{l}\text { Standard } \\
\text { tubes }\end{array}$ & $\begin{array}{l}\text { Blank } \\
\text { tubes }\end{array}$ & $\begin{array}{l}\text { Sample } \\
\text { tubes }\end{array}$ \\
\hline Barbital buffer II & 200 & 200 & 300 & 200 \\
\hline Sample & - & - & - & 500 \\
\hline Serum standard & - & 100 & - & - \\
\hline $\begin{array}{l}\text { Bovine serum albumin B } \\
\text { Corticotropin-free }\end{array}$ & 500 & 500 & 500 & - \\
\hline $\begin{array}{l}\text { serum } \\
\text { Corticotropin anti- }\end{array}$ & 100 & - & 100 & 100 \\
\hline $\begin{array}{l}\text { serum } \\
\text { [125 I]corticotropin }\end{array}$ & $\begin{array}{l}100 \\
100\end{array}$ & $\begin{array}{l}100 \\
100\end{array}$ & $\overline{100}$ & $\begin{array}{r}100 \\
-100\end{array}$ \\
\hline
\end{tabular}




\section{Results}

\section{Extraction}

The influence of the plasma background of individual samples on the efficiency of the Quso extraction step was studied in series of samples from five healthy subjects. From each subject, blood was taken from $8.00 \mathrm{~h}$ to $16.00 \mathrm{~h}$ at intervals of one hour. All samples were processed in one batch. Percentage recoveries of total $\left[{ }^{125} \mathrm{I}\right]$ corticotropin remaining in the plasma supernatant are listed in column 1 of Table 2 . No significant differences are apparent between the samples of one subject. An equivalent accordance is registered between four subjects, whereas non-extractable corticotropin amounts in the plasma of subject B.K. differ considerably from those of the other subjects. The $\left[{ }^{125} \mathrm{I}\right]$ corticotropin portion remaining in the plasma was removed only to a negligible extent by further Quso extraction. The percentage recoveries of $\left[{ }^{125} \mathrm{I}\right]$ corticotropin in the final acid desorbant solution (column 2 of Table 2) reflect the correspondent individual differences induced by the first extraction step.

\section{Desorption}

The potential loss of protein and acid equivalents from the bovine serum albumin solution $A$ in the course of the desorption step, which would be of importance for the incubation medium of the corticotropin standards, was evaluated by protein estimation and titration of proton equivalents before and after desorption. While protein loss was negligible $(<1 \%)$, concentration of protons decreased from $0.15 \mathrm{~mol} / 1$ to $0.115 \pm 0.002 \mathrm{~mol} / 1$ (S. D.) $(n=12)$.

\section{Analytical variables}

\section{Senisitivity}

In a preliminary study, we established that the CIS antisera applied in the present method provided highest affinity to the human corticotropin molecule when compared with other antisera commercially available to us (16). The affinity of this antiserum to different commer-

Tab. 2. Percentage recoveries of [ $\left.^{125} \mathrm{I}\right]$ corticotropin not extractable by Quso G32 from plasma (column 1) and desorbed from Qusọ by acid protein solution (column 2). 14 plasma samples of each subject were studied.

\begin{tabular}{|c|c|c|c|c|}
\hline \multirow[t]{2}{*}{ Subject } & \multicolumn{2}{|c|}{$\begin{array}{l}\text { Percentage }\left[{ }^{125} \tilde{I}\right] \text { cor- } \\
\text { ticotropin remaining } \\
\text { in plasma }\end{array}$} & \multicolumn{2}{|c|}{$\begin{array}{l}\text { Percentage }\left[{ }^{125} \text { I]cor- }\right. \\
\text { ticotropin desorbed } \\
\text { from Quso G32 }\end{array}$} \\
\hline & mean \pm & S. D. & mean : & S. D. \\
\hline $\begin{array}{l}\text { R.S. } \\
\text { B.F. } \\
\text { B.K. } \\
\text { M.R. } \\
\text { I.A. }\end{array}$ & $\begin{array}{l}17.73 \\
18.23 \\
37.1 .6 \\
18.39 \\
18.53\end{array}$ & $\begin{array}{l}0.66 \\
0.50 \\
1.90 \\
0.49 \\
0.66\end{array}$ & $\begin{array}{l}60.3 \\
61.8 \\
46.1 \\
62.2 \\
57.7\end{array}$ & $\begin{array}{l}2.95 \\
2.30 \\
1.50 \\
2.67 \\
4.40\end{array}$ \\
\hline mean & 22.00 & & 57.6 & \\
\hline
\end{tabular}

cially available corticotropin-standards was evaluated in terms of the mean affinity constants calculated according to the Scatchard plot technique $(15,17)$ and in terms of the molar amounts of standard necessary for $50 \%$ displacement of zero bound $\left[{ }^{125} \mathrm{I}\right]$ corticotropin radioactivity (tab. 3 ). While affinity and sensitivity differed only slightly between the 1-39 corticotropin standards (standard A, C, D and E), the synthetic 1-24 corticotropin standard B, however, provided significantly higher affinity to the antiserum applied if compared with the 1-39 corticotropin standards. In the present method, the corticotropin standard A was used throughout. The detection limit (2 S. D. from zero bound radioactivity) was found to be $0.71 \pm 0.14$ (S. D.) fmol corresponding to a final concentration of $1.47 \pm 0.29$ (S. D.) pmol/ 1 if an average recovery of $57.6 \%(\mathrm{tab} .2)$ is taken into account. The $50 \%$ intercept amounted to $6.49 \pm 0.93$ (S. D.) fmol corresponding to a final concentration of $13.52 \pm 1.93$ (S. D.) pmol/l. The lowest standard of the CIS-RIA kit processed without extraction (according to the manufacturer's instructions) amounts to $1.3 \mathrm{fmol}$, i.e. $13.3 \mathrm{pmol} / 1$ if a $100 \mu \mathrm{l}$ aliquot of plasma is assayed.

\section{Specificity}

There is complete cross reaction between porcine and human corticotropin (comparison of standards A, C and D). Further specifications as to the specificity of the antiserum used are outlined in the manufacturer's instructions.

\section{Precision}

Ten aliquots of one plasma sample were assayed in one assay. The coefficient of the intra-assay variability was found to be $5.67 \%$ in a sample of $13.3 \mathrm{pmol} / 1$. Interassay variability was assessed from a lyophilized plasma pool with a mean of $13.8 \mathrm{pmol} / 1$. Aliquots were reconstituted immediately before each assay. Coefficient of variation was $16.17 \%(n=8)$.

\section{Accuracy}

Human corticotropin in concentrations of $4.8,8.5,15.6$ and $33.6 \mathrm{pmol} / 1$ was added to corticotropin-free serum.

Tab. 3. Affinity of different corticotropin standards to the antiserum used in the present method. Information about the specific biological activity of standard $E$ was not available.

\begin{tabular}{llllll}
\hline & A & B & C & D & E \\
$\begin{array}{l}\text { Affinity constant } \\
\left(10^{11} \mathrm{l} / \mathrm{mol}\right)\end{array}$ & 3.1 & 8.4 & 1.9 & 2.8 & 1.2 \\
$\begin{array}{l}50 \% \text { intercept } \\
(\text { fmol) }\end{array}$ & 4.97 & 1.77 & 7.8 & 5.48 & 13.4 \\
$\begin{array}{l}50 \% \text { intercept } \\
(\mu \mathrm{IU})\end{array}$ & 4.69 & 0.52 & 5.61 & 3.69 & - \\
\hline
\end{tabular}


Each value was determined in duplicate. The equation of regression was:

Corticotropin $_{(\text {found })}=1.2 \mathrm{pmol} / 1+0.93 X$

corticotropin (added) . Coefficient of correlation was $r=$ 0.998 .

\section{Assay blanks}

Corticotropin immunoreactivities assessed from $2 \mathrm{ml}$ samples of water and charcoal-stripped serum respectively were found to be not significantly different from zero.

\section{Practicability}

The exclusion of any time consuming evaporation step promotes the present method as adequately practicable if compared with the classical extracting and concentrating techniques (17). Preparation of about 40 samples ready for RIA can be handled by one technician in about half a day. Total assay is completed by the subsequent RIA including overnight incubation within another day. A further considerable advantage of the present method, as to the interests of a routine laboratory, is represented by the commercial availability of all reagents.

Corticotropin in normal, stimulated and suppressed states

\section{Reference values}

Plasma of 48 apparently healthy persons was collected between $7.30 \mathrm{~h}$ and $10.00 \mathrm{~h}$. The reference range found was $6.5-10.9-18.5 \mathrm{pmol} / 1$ if a logarithmic distribution was considered. In table 4 , these values are compared with reference values reported in the literature.

\section{Suppression of pituitary activity}

Plasma corticotropin concentrations under the conditions of pituitary suppression were studied in five male

Tab. 4. Basal plasma corticotropin levels in man.

\begin{tabular}{|c|c|}
\hline $\begin{array}{l}\text { Plasma corticotropin } \\
(\mathrm{pmol} / \mathrm{l})\end{array}$ & Reference \\
\hline $\begin{aligned} & 33.5-84.4 \\
& 6.6-15.5 \\
& 0-17.7 \\
& 0-25.5 \\
& 2.6-12.2 \\
& 22.4 \pm 12.2 \text { (S. D.) } \\
& 4.8-38.8 \\
& 1.1-18.8 \\
& 3.3-15.5 \\
& 6.6 \\
& 22.6 \pm 5.9 \text { (S. D.) } \\
& 0-15.5 \\
& 6.9 \pm 3.5 \\
& 4.3 \pm 0.3 \\
& 9.1 \pm 7.5 \\
& 6.5-18.5\end{aligned}$ & $\begin{array}{l}\text { Yalow et al. } 1964(19) \\
\text { Demura et al. } 1966(20) \\
\text { Berson \& Yalow } 1968(1) \\
\text { Orth et al. } 1968(3) \\
\text { Landon \& Greenwood } 1968(21) \\
\text { Jensen et al. } 1971(22) \\
\text { Matsukura et al. } 1971(23) \\
\text { Donald } 1971(24) \\
\text { Besser et al. } 1971(25) \\
\text { Voigt et al. } 1971(26) \\
\text { Galskov } 1972(12) \\
\text { Croughs et al. } 1973(27) \\
\text { Müller et al. } 1978(10) \\
\text { Krieger et al. } 1979(28) \\
\text { Kao et al. } 1979(29) \\
\text { present method }\end{array}$ \\
\hline
\end{tabular}

subjects who received an infusion of hydrocortisone-21hemisuccinate $\left(20 \mathrm{mg} \mathrm{h}^{-1}\right)$ from $8.00 \mathrm{~h}$ to $13.00 \mathrm{~h}$. Base levels of plasma corticotropin at $8.00 \mathrm{~h}$ fell from $12.6 \pm$ 6.9 (S. D.) pmol/l to $4.4 \pm 3.1$ (S. D.) pmol/l at $13.00 \mathrm{~h}$.

\section{Stimulation of pituitary activity}

Changes of plasma corticotropin after stimulation of pituitary activity was studied in five male subjects, who were given an infusion of $800 \mathrm{mg}$ of metyrapone per hour from $8.00 \mathrm{~h}$ to $13.00 \mathrm{~h}$. Plasma corticotropin increased from $7.39 \pm 4.2$ (S. D.) pmol/1 at $8.00 \mathrm{~h}$ to $15.38 \pm 6.02$ (S. D.) pmol/1 at $16.00 \mathrm{~h}$.

\section{Discussion}

The extraction procedure involved in the estimation of plasma corticotropin hitherto was obviously responsible for the slow access of this parameter to the routine laboratory. The availability of high-affinity antisera as part of research methods (30) and also of the marketed CIS-RIA kit inaugurated the direct measurement of corticotropin in plasma, thus inducing widespread assessment of corticotropin in research as well as in routine laboratories $(13,31)$.

The data of the present study, however, point out some problems which have to be considered when practising direct estimation of plasma corticotropin. Firstly, the amounts of non-Quso-extractable corticotropin differing considerably between individual subjects (tab. 2) indicate the presence of corticotropin binding factors in plasma, which may interfere with the immunological reaction of the RIA. These findings, which are in complete accordance with the observations of Voigt et al. (9) may account for the anomalous results recently reported by Howe et al. using the CIS-RIA kit (14). Secondly, the sensitivity of the direct assay, although sufficient for the evaluation of elevated plasma levels of corticotropin, fails to detect plasma corticotropin in subnormal concentrations, which is of great interest for the differentiation between primary and secondary forms of disorders of the pituitary-adrenal axis. Using the direct technique of the CIS-RIA kit, a detection limit of $10 \mathrm{pmol} / 1$ was reported by Nakao et al. (31), thus covering just normal values. Therefore, one has to postulate that, for corticotropin estimation, a preceding extraction procedure is advisable because it reduces interfering plasma factors (5) and increases total assay sensitivity.

Originally, the present extraction procedure was processed according to the technique of Voigt et al. (9). Using theoretical alkaline equivalents for neutralization of the acid desorption solution, however, the $\mathrm{pH}$ of the medium shifted to higher values than in the corresponding standard solution, thus causing $\mathrm{pH}$-dependent differences in binding properties. This artefact was eliminated when that portion of proton equivalents irreversibly absorbed on the silica was taken into account. 
The divergency in normal values reported in the literature (tab. 4) and the problems involved in establishing true normal ranges have already been widely discussed (18). Some of these differences are undoubtedly caused by variations in time of sampling, technique and antisera used with different specificity to the corticotropin molecule or its fragments. A further reason for divergent values is the fact that procedural losses are considered in some cases (2), not in others (9). Furthermore, the different standards used in different laboratories may also contribute to the problematic comparability of normal corticotropin values. This point is emphasized by our findings of different affinities of some commercial corticotropin standards to the same antiserum, even when the molecular weight or the biological activity of the standard is taken into account (tab. 3). Thus, in view of external quality control, reference values of plasma cor- ticotropin will still remain a challenge and the establishment of a normal range for each laboratory is strongly advisable.

The validity of the present method with respect to its ability to monitor changes of plasma corticotropin in response to physiological stimuli is adequately documented. Particularly, it is demonstrated that suppressed values can be distinctly differentiated from normal values, thus showing the method to be suitable for the laboratory diagnosis of pituitary-adrenal disorders.

\section{Acknowledgement}

We are indebted to Prof. Dr. Koeppe, Department of Radiology, for providing computer facilities.

\section{References}

1. Berson, S. A. \& Yalow, R. S. (1968) J. Clin. Invest., 47, 2725-2751.

2. Krieger, D. T. \& Allen, W. (1975), J. Clin. Endocrinol. Metab., 40, 675-687.

3. Orth, D. N. (1974), in Methods of hormone radioimmunoassay (Jaffee, B. M. \& Behrman, H. R. eds.), pp. 125-160, Academic Press, New York.

4. Besser, G. M., Orth, D. N., Nicholson, W. E., Byyny, R. L. Abe, K. \& Woodham, J. P. (1971), J. Clin. Enocrinol. Metab., $32,595-603$.

5. Fehm, H. L., Voigt, K. H. \& Pfeiffer, E. F. (1972), Horm. Metab. Res., 4, 477-481.

6. Besser, G. M. (1973), Clin. Endocrinol. (Oxf.), 2, 175-186.

7. Horgan, E. D. \& Riley, W. J. (1974), Clin. Chem., 20, 682686.

8. Ratcliffe, J. G. \& Edwards, C. R. W. (1971), in Radioimmunöassay methods (Kirkham, K. E. \& Hunter, W. M., eds.), pp. 502-512, Churchill-Livingstone, Edinburgh.

9. Voigt, K. H., Fehm, H. L., Reck, R. \& Pfeiffer, E. F. (1974), Klin. Wochenschr., 52, 516-521.

10. Mülleri, O. A., Finke, R., Baur, X., Ehbauer, M., Madler, M. \& Scriba, P. C. (1978), GIT-Labor-Medizin, 2, 117-128.

11. Hummer, L. (1978), in Radioimmunoassay and related procedures in medicine, International Atomic Energy Agency, Vienna, pp. 391-402.

12. Galskov, A. (1972), Acta Endocrinol., 70, Suppl. 162, 1169.

13. Apter, D., Pakarinen, A., Hammond, G. L. \& Vihko, R. (1979), Acta Paediatr. Scand., 68, 599-604.

14. Howe, L. A. \& Smeaton, T. (1979), Clin. Chem., 25, 816817.

15. Schöneshöfer, M. (1977), Clin. Chim. Acta, 77, 101-115.

16. Schöneshöfer, M. \& Schefzig, B. (1978), Fresenius Z. Anal. Chem., 290, 165-166.
17. Scatchard, G. (1949), Ann. New York Acad. Sci., 51, 660672.

18. Donald, R. A. (1977) in Handbook of radioimmunoassay (Abraham, G. E., ed.), 319-390, Marcel Dekker, New York.

19. Yalow, R. S., Glick, S. M., Roth, J. \& Berson, S. A. (1964), J. Clin. Endocrinol. Metab., 24, 1219-1225.

20. Demura, H., West, C. D., Nugent, C. A., Nakagawa, K. \& Tyler, F. H. (1966), J. Clin. Endocrinol. Metab., 26, 12971302.

21. Landon, J. \& Greenwood, F. C. (1968), Lancet, I, 273-276.

22. Jensen, H. K. \& Blichert-Toft, M. (1971), Acta Endocrinol. $(\mathrm{Kbh}), 66,25-34$.

23. Matsukura, S., West, C. D., Ichikawa, Y., Jubiz, W., Harado, G. \& Tyler, F. H. (1971), J. Lab. Clin. Med., 77, 490-500.

24. Donald, R. A. (1971), J. Clin. Endocrinol. Metab., 32, 225231.

25. Besser, G. M., Cullen, D. R., Irvine, W. J., Ratcliffe, J. G. \& Landon, J. (1971), Br. Med. J., I, 374-376.

26. Voigt, K. H., Fehm, H. L. \& Pfeiffer, E. F. (1971), Horm. Metab. Res., 3, 313-317.

27. Croughs, R. J. M., Tops, C. F. \& DeJong, F. H. (1973), J. Endocrinol., 59, 439-449.

28. Krieger, D. T., Liotta, A. S., Suda, T., Goodgold, A. \& Condon, E. (1979), J. Clin. Endocrinol. Metab., 48, 566571.

29. Kao, P. C., Jiang, N. S. \& Carpenter, P. C. (1979), Clin. Chem., 25, 1267-1273.

30. Marten, J , Stark, E., Meretey, K. \& Schulster, D. (1978), J. Endocrinol., 78, 309-319.

31. Nakao, K., Nakai, Y., Oki, S., Horii, K. \& Imura, H. (1978), J. Clin. Invest., 62, 1395-1398.

Dr. Dr. M. Schöneshöfer Inst. f. Klin. Chemie Klinikum Steglitz Hindenburgdamm 30 D-1000 Berlin 45 
